\title{
Deleterious HDAC2 Gene Mutation
}

National Cancer Institute

\section{Source}

National Cancer Institute. Deleterious HDAC2 Gene Mutation. NCI Thesaurus. Code C156008.

A change in the nucleotide sequence of the HDAC2 gene that is associated with increased risk of disease. 